\title{
The Problems and Solutions of Dance Education in Universities
}

\author{
Lin Zhang \\ School of Music and Performance Art, Sichuan University of Arts and Science, Dazhou, China \\ Email: jjswendy@163.com
}

How to cite this paper: Zhang, L. (2019) The Problems and Solutions of Dance Education in Universities. Open Journal of Social Sciences, 7, 240-245.

https://doi.org/10.4236/jss.2019.75021

Received: April 15, 2019

Accepted: May 24, 2019

Published: May 27, 2019

Copyright $\odot 2019$ by author(s) and Scientific Research Publishing Inc. This work is licensed under the Creative Commons Attribution International License (CC BY 4.0)

http://creativecommons.org/licenses/by/4.0/

\begin{abstract}
In the dance education of universities, most of the training modes follow the traditional mode of the early professional universities. Even though there is a variety of teaching methods in dancing education in our country, there still exist many problems in the actual teaching process, such as emphasizing skills but ignoring theory, adopting indoctrinating teaching and neglecting the difference of individual students and the comprehensive development of students. This traditional dance teaching mode has greatly restricted the development of students, resulting in varied student proficiency and uncomprehensive development. In order to improve the overall dance teaching quality and promote the all-round development of students, teachers should start with the reform of classroom mode, innovate the dance teaching mode and comprehensively facilitate the construction of dance education mode in the new era.
\end{abstract}

\section{Keywords}

Dance Education, Indoctrinating Teaching, Comprehensive Development

\section{Introduction}

China has a long history in dancing which is a kind of emotional expression as well as body aesthetics. Dance, including modern dance, pole dance, ballet, traditional dance and etc., brings visual enjoyment. Therefore, it is of significant importance to improve teaching quality in universities.

\section{Dance Art}

Dance has a very long history. In primitive time before the word "dance" was created, the primitive people started showing some dance moves. During that 
period, the purpose of dance was to propose and mate. With the development of dance, people find that dance could be used to express feelings and emotion, and there is nothing like dance to carry out mental activities by body movements. Thus, dance has gradually become a way to express oneself. The saying goes "heart is touched, and uses the appropriate way to express". The dance movements reveal one's mental activities. Therefore, dance is a way to express one's strongest emotion. In modern dance, dance movements have been combined with all kinds of music, fully showing the dance itself, rather than displaying dance emotion. This kind of dance has gradually deviated from the original meaning of the dance. Therefore, the thought of integrating emotion into movements, movement is the carrier while emotion is what the dance wants to express should be realized through education. Nowadays, there are many kinds of dance in China, such as traditional dance, modern ballet, and pole dance. The new elements are added to dance like street dance and breakin', even aerobics is regarded as a kind of dance, which enriches dance education but gradually lose the core meaning of dance. The real dance art comes from life and emotion. Therefore, it is necessary to educate Chinese college students about dance emotion [1]. Dance not only contains a wide range of movements and rhythms, but also contains the inexpressible feelings of people.

\section{Current Situation of Dance Education in Universities}

\subsection{Low Degree of Perfection in Relative Courses}

The variety of dance courses demonstrates the demand from students. Every university enrolls thousands of students; students are more likely to choose the dance course according to their own interest and needs. In contrary, there are quite few dance courses available for students to choose which can't meet students' needs. Some students require basic courses like sculpt training [2]. While others who have dance foundation prefer advanced courses such as breakin' and poppin', which few people know it, not to mention have the corresponding teaching courses in universities. The reasons why universities fail to open the courses are the high cost of hiring professional dance teachers and setting up dance classes, most colleges and universities choose to ignore all-round development of dance education. At the same time, most of the dance courses in colleges and universities are mainly based on the characteristics of the school, most of the contents of the courses are to watch videos, enjoy dance performances, and the real substantive teaching is very few. This kind of teaching method that neglects the needs of students reduces the interest of students in dance learning and is not good for the development of dance education in colleges and universities.

\subsection{Less Professional Dance Teachers}

We should make great efforts to do a good job in the education to people's satisfaction. Education is the cornerstone of the rejuvenation of the China and social 
progress. We should give priority to education, comprehensively implement the Party's education policy, uphold the fundamental task of education in serving socialist modernization, and train socialist builders and successors with all-round development of morality, intelligence, physical health and beauty. We should implement quality education in an all-round way; deepen comprehensive reform of education, focus on improving education quality and cultivate students' spirit of innovation; encourage and guide social forces to set up education; strengthen the construction of teachers' ranks and improve teachers' moral standards and ability ; enhance teachers' sense of honor and sense of responsibility in teaching and educating people, which was also put forward by the 18th National Congress of the Communist Party. The quality of dance teaching in colleges and universities in China can be clearly demonstrated by the ability of its teachers. In dance education, the problem is that there are not many excellent dance teachers and teaching quality is low. Majority of teachers know few kinds of dance. The dance looks beautiful but without emotion. As many dance teachers are under temporary contract, they focus more on how to complete the courses and communicate less with students. In many cases, students want to listens to their teachers' advice but they do not have chance to talk to their teachers [3]. Furthermore, these teachers are less responsible. Some teachers simply complete their teaching task and do not tell students the core of the courses. This teaching standard is far from the requirements of dance education.

\subsection{Low Training Level of Dance Emotion}

There are few humanistic thoughts in dance teaching in colleges and universities. A dance with a soul requires the performer to pour into a great deal of emotion. In dance teaching in colleges and universities, teachers only pay attention to the teaching of dance movements, but not to teaching students what kinds of emotions to pour into for different dances. In college dance teaching, although teachers teach students a variety of dance skills, dance movements, and fully express the beauty through different forms of movement, but such dance can only be appreciated by those who have a shallow understanding of the content of the dance. A true professional dancer will not rate such a dance as excellent. One of the main points is that such a dance can at best be perfect physically but without the shock of the spirit. The deviation in cognition of college teachers makes it impossible to improve the dance teaching quality in colleges and universities, and the students cannot learn the essence of dance education.

\subsection{Limited Course Selection}

In current situation, there are few dance courses such of freestyle dance, street dance, Latin and etc. sports dance is most popular amongst students. However, less popular dances such as traditional dance course is not available in universities. Even if some universities open traditional dance course, the teaching quality is not high. It is impossible to set all kinds of dance courses in universities like he 
hip-hop style of the Fonk, reggae dance, classical dance ballet, sports dance skating, water dance, street hip-hop and etc. whereas, it is necessary to set up courses to add the elements of educational dance, modern dance and creative dance. Additionally, disco dance is not popular amongst students, however, new modern disco is quite popular to the public. So it is necessary to enrich the dance education in universities by adding more elements into dance.

\subsection{Less Innovative Teaching Mode}

The size of class is more than ten students. Students standing at the back row can hardly watch their teacher in front. The format of teaching in class is to warm up first, then the teacher demonstrates every single movement. There are many things to be taught in one class and students can hardly remember all as they cannot take notes during the class [4]. Furthermore, it is impossible that the teacher instructs each student. In this case, a lot of problems cannot be corrected instantly. Besides, students feel exhausted in the class and they do not gain anything. Gradually, they lose the interest in class. So, dance courses cannot be carried out smoothly in universities.

\section{The Plan of Improving Dance Teaching Quality in Universities}

\subsection{To Increase Teaching Funds}

Colleges and universities should pay more attention to dance education, and increasing the investment of funds is the most important. The increasing investment in dance teaching can create a large number of objective environments for dance teaching, such as the construction of dance classroom, the renewal of teaching equipment, the props and costumes used in dance performances, and so on. While improving the objective environment, colleges and universities should often organize students to perform dance performances and competitions, increase students' learning enthusiasm, and at the same time attract more people to devote their attention to dance learning. So that dance is no longer a student's personal hobby, but also for a multi-audience performance.

\subsection{To Recruit Excellent Dance Teachers}

In dance education in colleges and universities, the strength of teaching staff is very important, and teachers are also the embodiment of dance teaching level in a university. Therefore, colleges and universities should select dance teachers carefully. In the selection of teachers, if they cannot employ a large number of full-time teachers through formal recruitment, they should at least make the individual dance teachers hired to be highly educated, conscientiously responsible in the course of teaching. At the same time, the treatment of dance teachers should be improved accordingly. After class, teachers are asked to stay in class longer, so that students can fully ask questions and communicate with teachers when they encounter problems. 


\subsection{To Enhance the Infusion of Emotion}

In the process of dance teaching, college teachers should pay attention to teaching students how to express their inner feelings through dance movements. The teacher will show the students a lot of videos performed by the professional dancers and show them the feelings in the dance through the performance. The teacher should also teach the special movements of emotion expression in dance, such as what kind of dance movements should be used to express sadness, what kind of body posture and facial expressions should be used to express happiness. Only through a large number of professional teachings can students understand the charm of dance, so as to better learn dance.

\subsection{To Set up Various Dance Courses}

Universities should enrich the curriculum. Especially in some ethnic minority areas, students contact with ethnic dance very much and have very deep love of ethnic dance [5]. Therefore, in the teaching of colleges and universities, students cannot be separated from this national habit; on the contrary, a lot of support should be given. Teachers can employ professional national dance teachers to teach the corresponding Dai dance, Yao dance and other minority dance, so that students can fully retain their dance hobbies in dance teaching in colleges and universities and students can have a deeper understanding of folk dance. In the teaching of other dances, such as hip-hop, free dance, mechanical dance and so on, the teaching of these dances is not the traditional way of classroom teaching. Teachers should add more personal performance links, such as in hip-hop classes. Teachers can organize students to form a large circle so that students can volunteer to perform hip-hop dance. This teaching method is relatively easy and can also create a learning atmosphere for hip-hop dance. By performing, students can be more self-confident and make more perfect performance. This kind of teaching method can not only enrich the dance teaching content, but also create a passionate teaching atmosphere for the students, and promote the dance teaching in colleges and universities to go further.

\subsection{To Update Teaching Mode}

The teaching mode needs to be optimized and updated. First, the number of students in one class should be reduced. The ratio of teacher and students in one class should be around 1 to 15 . Second, the teacher should clearly demonstrate every movement and emotions in dance before teaching. Teachers can also take students to watch live show to inspire the students in their learning. Dance learning is a long-term process, from basic body sculpt training to how to express emotions properly, it requires consistent practice. Teachers need to encourage and support students during their learning. At the same time, teachers should encourage students to participate in performance and competition so that students gain more experience and confidence. 


\section{Conclusion}

I put forward some problems and countermeasures according to the present situation of dance teaching in universities. The good development of dance teaching in universities requires the joint efforts of schools, teachers and students. Schools should pay more attention to dance teaching, enrich the curriculum and content of dance teaching, teachers should be more accountable, students should be more enthusiastic about dance performance. Excellent dance art brings people enjoyment. College teachers should shoulder the mission of cultivating talents, actively achieve the goal of education, implement national policies, export high-quality talents for society, lay a good foundation for the construction of national spiritual civilization, and flourish the art of dance.

\section{Conflicts of Interest}

The author declares no conflicts of interest regarding the publication of this paper.

\section{References}

[1] He, X.Y. (2018) Strategies for Improving Students' Expression in Dance Teaching in Colleges and Universities. Wen Cun Journal, No. 1, 65.

[2] Liu, X. (2017) On the Present Situation of Dance Teaching and Its Improvement Strategies in Colleges and Universities. Shenzhou, No. 28, 172.

[3] Chen, L.L. (2017) Analysis on the Deficiency and Improvement Strategy of Dance Teaching in Colleges and Universities. Shanxi Youth, No. 13, 273.

[4] Ma, D.X. (2017) Strengthen the Construction of Young Teachers' Ethics in Colleges and Universities. Journal of the Chinese People's Political Consultative Conference, 2017-03-01(010).

[5] Gao, L.X. (2017) On the Application of Red Cultural Resources in College Dance Creation. Literature Life, No. 12, 94, 98. 